\title{
Heparan sulfate proteoglycan-dependent neutrophil chemotaxis toward PR-39 cathelicidin
}

\author{
Angela Djanani ${ }^{1}$, Birgit Mosheimer ${ }^{1}$, Nicole C Kaneider ${ }^{1}$, \\ Christopher R Ross ${ }^{2}$, Giovanni Ricevuti ${ }^{3}$, Josef R Patsch ${ }^{1}$ and \\ Christian J Wiedermann*1
}

\begin{abstract}
Address: ${ }^{1}$ Laboratory of Medical Intensive Care, Division of General Internal Medicine, Department of Medicine, Medical University of Innsbruck, Anichstrasse 35, A-6020 Innsbruck, Austria, ${ }^{2}$ Department of Anatomy and Physiology, College of Veterinary Medicine, Kansas State University, Coles Hall 228, 1600 Denison Avenue, Manhattan, KS 66506-5602, USA and ${ }^{3}$ Department of Internal Medicine and Therapeutics, Section of Internal Medicine, University of Pavia, Viale Liberta, I-27100 Pavia, Italy
\end{abstract}

Email: Angela Djanani - angela.djanani@uibk.ac.at; Birgit Mosheimer - birgit.mosheimer@uibk.ac.at; Nicole C Kaneider - nicole.kaneider@uibk.ac.at; Christopher R Ross - ross@vet.k-state.edu; Giovanni Ricevuti - giovanni.ricevuti@unipv.it; Josef R Patsch - josef.patsch@uklibk.ac.at; Christian J Wiedermann* - christian.wiedermann@asbz.it

* Corresponding author

Published: 02 November 2006

Journal of Inflammation 2006, 3:14 doi:10.1186/1476-9255-3-14
Received: 30 August 2006

Accepted: 02 November 2006

This article is available from: http://www.journal-inflammation.com/content/3/1//4

(C) 2006 Djanani et al; licensee BioMed Central Ltd.

This is an Open Access article distributed under the terms of the Creative Commons Attribution License (http://creativecommons.org/licenses/by/2.0), which permits unrestricted use, distribution, and reproduction in any medium, provided the original work is properly cited.

\begin{abstract}
Cathelicidins are mammalian proteins containing a C-terminal cationic antimicrobial domain. Porcine PR-39 cathelicidin affects leukocyte biology. Mechanisms of action may involve alteration of heparan sulfate proteoglycan-dependent functions in inflammatory cells. It was tested whether PR-39 affects human neutrophil migration and if such effects involve heparan sulphate proteoglycans. Neutrophils were from forearm venous blood of healthy donors. Migration was tested in modified Boyden chamber assays. Involvement of heparan sulfate proteoglycans was tested by their chemical modification and by the use of specific antibodies. PR-39 induced migration in neutrophils in a concentration dependent manner. Modification of heparan sulfate proteoglycans with sodium chlorate inhibited migration whereas chemotaxis toward the chemoattractant formylMet-Leu-Phe was not affected. Removal of heparan sulfates or chondroitin sulfates from the surface of neutrophils by heparinase or chondroitinase inhibited migration toward PR-39. In conclusion, antimicrobial PR-39 stimulates human neutrophil chemotaxis in a heparan sulfate proteoglycandependent manner. Involvment of syndecans is likely as both heparinase and chondroitinase were abrogating. Data suggest active participation of heparan sulfate proteoglycans of neutrophils in cathelicidin peptide-mediated regulation of the antimicrobial host defense.
\end{abstract}

\section{Findings}

Peptides with in vitro antimicrobial activity have been identified from several gene families. Two major antimicrobial peptide families in mammals are the defensins [1] and the cathelicidin peptides [2-4]. It is known that the defensin structure is based on a common beta sheet core, which is stabilized by three disulfide bonds $[1,2]$ but cathelicidins are highly heterogeneous. Their conserved cathelin domain sequence has been used as a genetic probe enabling the discovery of numerous new members of this family [4-10]. Circulating neutrophils, myeloid bone marrow cells and epithelial surfaces are an impor- 
tant source of cathelicidine expression [7,11-14]. The cathelicidin, prolin-arginine-rich 39 peptide (PR-39), first isolated from the porcine small intestine [15] was also identified in porcine neutrophils [16]. Different forms occur and PR-39 isolated from porcine small intestine is sligthly different in composition from that isolated from porcine neutrophils [17]. PR-39 posseses antibacterial activity [18] and has the ability to induce syndecan expression in wounds in animal studies [12]. PR-39 kills bacteria by a mechanism that stops protein and DNA synthesis after a lag period of about 8 min [18]. PR-39 is an inhibitor of neutrophil function in injured mice, is involved in metastatic activity of human tumor cells, and can induce angiogenesis $[1-3,19,20]$. These observations suggest that the efficacy of PR-39 is not species specific.

Heparan sulfate proteoglycans (HSPG) from endothelium and leukocytes interact with P-selectin, an important adhesion molecule regulating leukocyte adhesion and migration [21]. HSPG localize to granules of myeloid cells including monocytes and neutrophils [22], and expression of mRNA for syndecan core protein has been detected in different types of leukocytes including neutrophils [23,24]. As PR-39 is abundantly expressed in mammalian tissues and is best investigated among cathelicidins, our motivation in this project was to determine if porcine PR-39 affects human neutrophil migration and whether such effects involve HSPG.

Heparinase I and chondroitinase ABC were from Sigma Chemical Corp. (St. Louis, MO, USA). PR-39 was synthesized by solid-phase method with greater than $90 \%$ purity [25]. Antibodies against the core-protein of syndecan-4 (D-16) and the ectodomain of this proteoglycan (5G9) were affinity purified goat polyclonal antibodies raised against peptides mapping with the respective regions of the human syndecan-4 protein (both Santa Cruz Inc., Wiltshire, England). According to the manufacturers instructions, suitability of its use has been demonstrated for detection of syndecan-4 as well as for use as control antibodies in siRNA studies. Other reagents not further specified were also from Sigma. Neutrophils were obtained from forearm venous blood of healthy volunteers, anticoagulated with $1.6 \mathrm{mg}$ EDTA/mL of blood. Neutrophil preparation was performed as described [26]. Cell preparations yielded > 95\% neutrophils (by morphology in Giemsa stains) and > 99\% viability (by trypan dye exclusion). Chemotaxis of neutrophils into cellulose nitrate to gradients of soluble attractants was measured in RPMI 1640/0.5\% BSA using a 48-well microchemotaxis chamber (Neuroprobe, Bethesda, MD, USA) in which a 5 $\mu \mathrm{m}$ pore-sized filter (Sartorius, Göttingen, Germany) separates the upper and lower chamber as previously described [26]. When PR-39 was used as attractant, concentrations ranging from $10 \mathrm{mmol} / \mathrm{L}$ to $1 \mathrm{nmol} / \mathrm{L}$ were tested. As positive control chemotactic agent in the lower chamber fMLP was used. For some experiments cells were pretreated with heparinase I, an enzyme that cleaves highly sulfated regions of heparan sulfate-like glycosaminoglycans at 2-O-sulfated uronic acids, for $50 \mathrm{~min}$. Thereafter cells were washed twice before testing for chemotaxis. For other experiments cells were pretreated with chondroitinase $\mathrm{ABC}$ also for $50 \mathrm{~min}$ that cleaves chondroitin sulfate side chains of cell surface proteoglycans. Since it is known that sodium chlorate is able to modify proteoglycan sulfation, we tested PR-39 chemotaxis after pre-treatment of cells for 20 min with sodium chlorate. As neutrophil migration toward PR-39 might be mediated via syndecan-4, chemotaxis experiments were performed in the presence of monoclonal antibodies toward the core-protein of syndecan- 4 and a side chain of this proteoglycan. Cells were incubated with these antibodies for $20 \mathrm{~min}$, washed twice and allowed to migrate toward PR-39.

Data are expressed as mean and standard error of the mean (S.E.M.). Means were compared by Kruskal-Wallis analysis of variance and by Mann-Whitney u-test for nonparametric samples (Abacus Concepts, Berkley, CA). A difference with $\mathrm{p}<0.05$ was considered to be significant.

To determine whether PR-39 induces human neutrophil chemotaxis, we tested in vitro migration of the cells at a wide range of concentrations $[10 \mathrm{mmol} / \mathrm{L}$ to $1 \mathrm{nmol} / \mathrm{L}]$. PR-39 induced human neutrophil chemotaxis in a concentration dependent manner with a maximum effect at $10 \mu \mathrm{mol} / \mathrm{L}$ (data not shown). To investigate the role of intact HSPG on the surface of neutrophils in PR-39induced cell migration, neutrophils were pretrated for 50 min with heparinase I or chondroitinase [both, $50 \mathrm{nU} / \mathrm{mL}$ to $50 \mathrm{mU} / \mathrm{mL}$ ] at $37^{\circ} \mathrm{C}$, followed by two washing steps. As glypicans carry heparan sulfate side chains but not chondroitin sulfate side chains, whereas syndecans carry both [27], experiments were performed with both heparinase I and chondroitinase. Results showed a concentrationdependent reduction of migration by removal of these two substrates from the cell surface, whereas chemotactic effects of fMLP [10 nmol/L] were not affected (Fig. 1). To investigate the effect of sodium chlorate which is known to modify sulfation of proteoglycans and sulphated proteins in cell culture, neutrophils were pretreated with sodium chlorate $[10 \mathrm{mmol} / \mathrm{L}$ to $40 \mathrm{mmol} / \mathrm{L}]$, washed, and then allowed to migrate towards PR-39. Neutrophil chemotaxis to PR-39 was significantly inhibited by sodium chlorate whereas chemotaxis toward the chemokine IL-8 used as alternative control attractant was not affected (data not shown).

Because PR-39-induced chemotaxis was inhibited by chondroitinase and heparinase I, we suggested the 

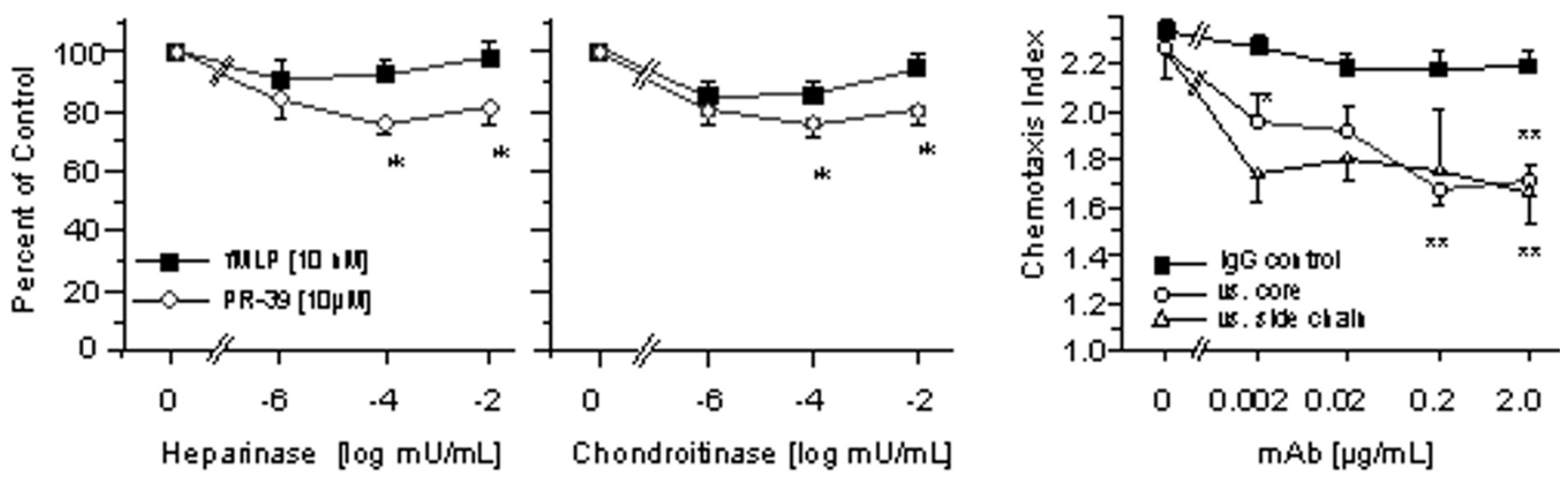

Figure I

Effects of heparinase, chondroitinase and anti-syndecan 4 antibodies on PR-39-induced chemotaxis of neutrophils. Heparinase I (left panel) or chondroitinase (middle panel) was added to neutrophils. After an incubation (humidified, $37^{\circ} \mathrm{C} / 5 \% \mathrm{CO}_{2}$ ) period of $50 \mathrm{~min}$, cells were washed twice and chemotaxis assays were performed. PR-39 [ $\left.10 \mu \mathrm{mol} / \mathrm{L}\right]$ was used as chemoattractant and $\mathrm{fMLP}[10 \mathrm{nmol} / \mathrm{L}]$ served as control attractant. Data are expressed as percent of medium control (pretreatment with medium), with a distance of migration toward fMLP of $79.8 \pm 3.1 \mu \mathrm{m}$, towards PR-39 of $66.8 \pm I .3(n=4)$. Statistical analysis: Mann-Whitney U-test versus medium control, $*, p<0.05$ after Kruskal-Wallis test, $p<0.05$. Effects of antibodies to syndecan-4 core protein or syndecan-4 chain epitopes (right panel) were tested by preincubation of neutrophils for 20 minutes (humidified $37^{\circ} \mathrm{C} / 5 \% \mathrm{CO}_{2}$ ). After washing, cells were allowed to migrate toward PR-39 [ $\left.10 \mu \mathrm{mol} / \mathrm{L}\right]$ in modified Boyden chambers using nitrocellulose micropore filters. Isotype matched lgG served as control. Results are given as mean \pm SEM of the chemotaxis index, which is the ratio between the distance of migration toward attractant and that toward control. Distance of random migration was $40.0 \pm 2.78(n=4)$. Statistical analysis: Mann-Whitney U-test versus no antibody, ${ }^{*} p<0.05$ after Kruskal-Wallis test $p<0.05$.

involvement of syndecans but not glypicans by PR-39. Moreover, in vivo expression of syndecans has been reported as being affected by PR-39 [12]. Therefore, chemotaxis of neutrophils toward PR-39 was tested in the presence of migration-blocking monoclonal antibodies to syndecan-4 core protein or a syndecan-4 side chain because this pathway was shown to affect the cell's motility. Neutrophils were again pre-treated with either of the two antibodies or an isotype-matched $\operatorname{IgG}$, and then allowed to migrate toward PR-39 [10 $\mu \mathrm{mol} / \mathrm{L}]$. The antibodies specifically inhibited neutrophil migration toward PR-39 (Fig. 1).

In the present study, PR-39 stimulated human neutrophil chemotaxis in a bell-shaped dose-response curve. PR-39 is known to induce chemotaxis in porcine neutrophils [25]. As PR-39 is effective in improving survival in animals models of severe sepsis $[28,29]$. the observation that PR39 affects neutrophil function accross different species may be of relevance if PR-39 is further developed for potential use in severe sepsis. In porcine leukocyte chemotaxis, peak responses occurred at 0.5 to 2 micromoles per liter [25] which correlates well with PR-39 effects on human neutrophils (data not shown). This finding suggests that exogenous PR-39 may play a role not only in animal but also in human inflammation.
For LL-37, the only human cathelicidin identified so far, it was proposed that chemotactic responsiveness of leukocytes involves formyl peptide receptor-like 1, and activation of this formyl peptide receptor-like 1 crossdeactivates LL-37 responsiveness [30]. In mast cell responses to cathelicidins, there may be two types of receptors involved, a high affinity receptor responsible for chemotaxis, and a low affinity receptor with undefined function [31]. Detailed biochemical mechanisms or a biochemical characterization of these binding sites, however, remained unknown.

Antithrombin-III, a prototypical glycosaminoglycan ligand, has only recently been identified to exert direct effects on cells of the innate immune system via HSPG [26,32]. Already two decades ago, consensus sequences for glycosaminoglycan recognition were determined as [$\mathrm{X}-\mathrm{B}-\mathrm{B}-\mathrm{X}-\mathrm{B}-\mathrm{X}-\mathrm{]}$ and [-X-B-B-B-X-X-B-X-] where $\mathrm{B}$ is the probability of a basic residue and $X$ is a hydropathic residue, which form potential nucleation sites for the recognition of polyanions in proteins [33]. As antimicrobial peptides including defensins and cathelicidins contain consensus sequences for HSPG recognition [34], we further explored the roles of HSPG in mediating PR-39 effects in neutrophil migration. Heparan sulfate chains abound on syndecans and glypicans which can bind a rep- 
ertoire of proteins. Thereby, HSPG can immobilize the ligands, increase its local concentration, change its conformation, present it to a signalling receptor and enhance the formation of receptor-ligand signaling complexes [35]. Modification of these heparan sulfate chains could influence cell function. To further substantiate the role of HSPG in the response of neutrophils to PR-39, cells were pretreated with the sulfation inhibitor, sodium chlorate [36]. This pretreatment dose-dependently inhibited responiveness of the cells to PR-39. Moreover, of the two families of membrane-bound HSPG, the syndecans, by containing mixtures of the two major types of glycosaminoglycan chains found in animal cells, namely heparan sulfate and chondroitin sulfate, exemplify hybrid proteoglycans. In contrast, the glypicans appear to contain only heparan sulfate chains [37]. To examine if chondroitin sulfate proteoglycans act as putative interaction site for PR-39, neutrophils were treated with chondroitinase before testing cell migration. Data imply that PR-39's effects on cell migration are sensitive to both heparinase I and chondroitinase suggesting that of HSPG, syndecans mediate direct cellular actions of PR-39. By cleaving this specific site enzymatically with heparinase or chondroitinase or by chemically modifying them with sodium chlorate, chemotactic effects of PR-39 were altered. These observations not only confirm the role of HSPG in leukocyte function but also functionally establish that syndecans are involved in signalling effects of the cathelicidin in leukocytes.

The syndecan family of cell surface proteoglycans has been implicated in a number of biological processes, including blood coagulation, cell adhesion, signal transduction and wound repair [38]. Originally found on epithelial cells, syndecans were later shown to be present in several other mesenchyma-derived cell types, including fibroblast, smooth muscle cells, and neutrophils [28].

PR-39 has been shown to interact with a domain within the integrin mediated signaling protein, namly p130(Cas) [39], an assembling molecule of actin filaments which promotes cell movement, cell migration, and cell spreading in fibroblasts [40]. Identification of p130(Cas) as a mediator of focal adhesion kinase-promoted cell migration [41] fits well to its interaction with PR-39, given the finding that syndecan- 4 modulates focal adhesion kinase phosphorylation [42] and may be activated by PR-39 as suggested by our observed inhibition of PR-39-induced chemotaxis of neutrophils with antibodies to syndecan-4. This hypothesis, however, requires biochemical confirmation.

The data provided do not permit the conclusion that only syndecan-4 mediates the chemotaxis of human neutrophils to PR-39. Other syndecans or glypicans may also participate in coordinating the chemotactic response, as additional cell surface proteoglycans harboring HS and/or CS might also be involved.

To summarize, besides proposed involvement of formyl peptide receptor-like 1, no signalling pathway for cathelicidins in neutrophils had been identified so far. Our results provide strong evidence for interactions of PR-39 with proteoglycans on the surface of leukocytes. Biochemical and functional tests identify syndecan- 4 as a putative acceptor site for PR-39 which contains consensus sequences for glycosaminoglycan recognition. Our findings may be of particular relevance if PR-39 proofs have a therapeutic potential in neutrophil-mediated inflammatory diseases.

\section{Abbreviations \\ BSA - Bovine serum albumin \\ fMLP - formyl-Met-Leu-Phe \\ HSPG - Heparan sulfate proteoglycan \\ PR-39 - Prolin-arginine-rich 39 peptide}

\section{Competing interests}

The author(s) declare that they have no competing interests.

\section{Authors' contributions}

$\mathrm{AD}$ carried out the chemotaxis experiments and drafted the manuscript. BM and NCK carried out the enzyme digestion and antibody inhibition studies, respectively. CRR, GR and JRP participated in the design of the study. CJW conceived of the study, and participated in its design and coordination and helped to draft the manuscript. All authors read and approved the final manuscript.

\section{Acknowledgements}

The study was partly supported by the „Verein zur Förderung von Forschung und Fortbildung in Klinischer Kardiologie und Intensivmedizin - Innsbruck, Österreich“.

\section{References}

I. Lehrer RI, Ganz T: Defensins of vertebrate animals. Curr Opin Immunol 2002, 14:96-102.

2. Lehrer RI, Ganz T: Cathelicidins: a family of endogenous antimicrobial peptides. Curr Opin Hematol 2002, 9: 18-22.

3. Zaiou M, Gallo RL: Cathelicidins, essential gene-encoded mammalian antibiotics. J Mol Med 2002, 80:549-6I.

4. Zanetti M, Gennaro R, Romeo D: Cathelicidins: a novel protein family with a common proregion and a variable C-terminal antimicrobial domain. FEBS Lett 1995, 374: I-5.

5. Zanetti M, Del Sal G, Storici P, Schneider C, Romeo D: The cDNA of the neutrophil antibiotic Bac5 predicts a pro-sequence homologous to a cysteine proteinase inhibitor that is common to other neutrophil antibiotics. J Biol Chem 1993, 268:522-6.

6. Bagella L, Scocchi M, Zanetti M: cDNA sequences of three sheep myeloid cathelicidins. FEBS Lett 1995, 376:225-8. 
7. Gallo RL, Kim KJ, Bernfield M, Kozak CA, Zanetti M, Merluzzi L, Gennaro R: Identification of CRAMP, a cathelin-related antimicrobial peptide expressed in the embryonic and adult mouse. J Biol Chem 1977, 272: I3088-93.

8. Agerberth B, Gunne H, Odeberg J, Kogner P, Boman HG, Gudmundsson GH: FALL-39, a putative human peptide antibiotic, is cysteine-free and expressed in bone marrow and testis. Proc Natl Acad Sci USA 1995, 92: 195-9.

9. Storici P, Scocchi M, Tossi A, Gennaro R, Zanetti M: Chemical synthesis and biological activity of a novel antibacterial peptide deduced from a pig myeloid cDNA. FEBS Lett 1994, 337:303-7.

10. Tossi A, Scocchi M, Zanetti M, Storici P, Gennaro R: PMAP-37, a novel antibacterial peptide from pig myeloid cells. cDNA cloning, chemical synthesis and activity. Eur J Biochem 1995, 228:94|-6.

II. Zanetti M, Litteri L, Gennaro R, Horstmann H, Romeo D: Bactenecins, defense polypeptides of bovine neutrophils, are generated from precursor molecules stored in the large granules. J Cell Biol 1990, I I I:|363-7I.

12. Gallo RL, Ono M, Povsic T, Page C, Eriksson E, Klagsbrun M, Bernfield $M$ : Syndecans, cell surface heparan sulfate proteoglycans, are induced by a proline-rich antimicrobial peptide from wounds. Proc Natl Acad Sci USA 1994, 9 I: I I035-9.

13. Frohm NM, Sandstedt B, Sorensen O, Weber G, Borregaard N, Stahle-Backdahl M: The human cationic antimicrobial protein (hCAP I 8), a peptide antibiotic, is widely expressed in human squamous epithelia and colocalizes with interleukin-6. Infect Immun 1999, 67:2561-6.

14. Sorensen O, Arnljots K, Cowland JB, Bainton DF, Borregaard N: The human antibacterial cathelicidin, hCAP- 18 , is synthesized in myelocytes and metamyelocytes and localized to specific granules in neutrophils. Blood 1997, 90:2796-803.

15. Agerberth B, Lee JY, Bergman T, Carlquist M, Boman HG, Mutt V, Jornvall H: Amino acid sequence of PR-39. Isolation from pig intestine of a new member of the family of proline-argininerich antibacterial peptides. Eur J Biochem I991, 202:849-54.

16. Shi J, Ross CR, Chengappa MM, Blecha F: Identification of a proline-arginine-rich antibacterial peptide from neutrophils that is analogous to PR-39, an antibacterial peptide from the small intestine. J Leukoc Biol 1994, 56:807-I I.

17. Shi J, Ross CR, Chengappa MM, Sylte MJ, McVey DS, Blecha F: Antibacterial activity of a synthetic peptide (PR-26) derived from PR-39, a proline-arginine-rich neutrophil antimicrobial peptide. Antimicrob Agents Chemother 1996, 40:1 I5-2I.

18. Boman HG, Agerberth B, Boman A: Mechanisms of action on Escherichia coli of cecropin PI and PR-39, two antibacterial peptides from pig intestine. Infect Immun 1993, 61:2978-84.

19. Ohtake T, Fujimoto Y, Ikuta K, Saito H, Ohhira M, Ono M, Kohgo Y: Proline-rich antimicrobial peptide, PR-39 gene transduction altered invasive activity and actin structure in human hepatocellular carcinoma cells. Br / Cancer 1999, 8:393-403.

20. Li J, Post M, Volk R, Gao Y, Li M, Metais C, Sato K, Tsai J, Aird W, Rosenberg RD, Hampton TG, Sellke F, Carmeliet P, Simons M: PR39, a peptide regulator of angiogenesis. Nat Med 2000, 6:49-55.

21. Koenig A, Norgard-Sumnicht K, Linhardt R, Varki A: Differential interactions of heparin and heparan sulfate glycosaminoglycans with the selectins. Implications for the use of unfractionated and low molecular weight heparins as therapeutic agents. J Clin Invest 1998, I0 I:877-89.

22. Parmley RT, Hurst RE, Takagi M, Spicer SS, Austin RL: Glycosaminoglycans in human neutrophils and leukemic myeloblasts: ultrastructural, cytochemical, immunologic, and biochemical characterization. Blood 1983, 61:257-66.

23. Yeaman C, Rapraeger AC: Membrane-anchored proteoglycans of mouse macrophages: P388D I cells express a syndecan-4like heparan sulfate proteoglycan and a distinct chondroitin sulfate form. I Cell Physiol 1993, 1 57:413-25.

24. Yeaman C, Rapraeger AC: Post-transcriptional regulation of syndecan- $I$ expression by cAMP in peritoneal macrophages. J Cell Biol 1993, I22:94I-50.

25. Huang HJ, Ross CR, Blecha F: Chemoattractant properties of PR-39, a neutrophil antibacterial peptide. J Leukoc Biol 1997, 61:624-9.

26. Dunzendorfer S, Kaneider N, Rabensteiner A, Meierhofer C, Reinisch C, Romisch J, Wiedermann C): Cell-surface heparan sulfate pro- teoglycan-mediated regulation of human neutrophil migration by the serpin antithrombin III. Blood 200I, 97:1079-85.

27. Mertens G, Cassiman JJ, Van den Berghe H, Vermylen J, David G: Cell surface heparan sulfate proteoglycans from human vascular endothelial cells. Core protein characterization and antithrombin III binding properties. J Biol Chem 1992, 267:20435-43.

28. James PE, Madhani M, Ross C, Klei L, Barchowsky A, Swartz HM: Tissue hypoxia during bacterial sepsis is attenuated by PR-39, an antibacterial peptide. Adv Exp Med Biol 2003, 530:645-52.

29. Madhani M, Barchowsky A, Klei L, Ross CR, Jackson SK, Swartz HM, James PE: Antibacterial peptide PR-39 affects local nitric oxide and preserves tissue oxygenation in the liver during septic shock. Biochim Biophys Acta 2002, 1588:232-40.

30. De Y, Chen Q, Schmidt AP, Anderson GM, Wang JM, Wooters J, Oppenheim JJ, Chertov O: LL-37, the neutrophil granule- and epithelial cell-derived cathelicidin, utilizes formyl peptide receptor-like I (FPRLI) as a receptor to chemoattract human peripheral blood neutrophils, monocytes, and T cells. J Exp Med 2000, 192:1069-74.

3I. Niyonsaba F, Iwabuchi K, Someya A, Hirata M, Matsuda H, Ogawa H, Nagaoka I: A cathelicidin family of human antibacterial peptide LL-37 induces mast cell chemotaxis. Immunology 2000, 106:20-6.

32. Kaneider NC, Egger P, Dunzendorfer S, Wiedermann CJ: Syndecan4 as antithrombin receptor of human neutrophils. Biochem Biophys Res Commun 200I, 287:42-6.

33. Cardin AD, Weintraub HJ: Molecular modeling of protein-glycosaminoglycan interactions. Arteriosclerosis 1989, 9:21-32.

34. Andersson E, Rydengard V, Sonesson A, Morgelin M, Bjorck L, Schmidtchen A: Antimicrobial activities of heparin-binding peptides. Eur J Biochem 2004, 27 I: 12 19-26.

35. Bernfield M, Gotte M, Park PW, Reizes O, Fitzgerald ML, Lincecum J, Zako M: Functions of cell surface heparan sulfate proteoglycans. Annu Rev Biochem 1999, 68:729-77.

36. Wadstrom $T$, Ljungh A: Glycosaminoglycan-binding microbial proteins in tissue adhesion and invasion: key events in microbial pathogenicity. J Med Microbiol I999, 48:223-33.

37. Kjellen L, Lindahl U: Proteoglycans: structures and interactions. Annu Rev Biochem 1991, 60:443-75.

38. Bernfield M, Kokenyesi R, Kato M, Hinkes MT, Spring J, Gallo RL, Lose E): Biology of the syndecans: a family of transmembrane heparan sulfate proteoglycans. Annu Rev Cell Biol I992, 8:365-93.

39. Chan YR, Gallo RL: PR-39, a syndecan-inducing antimicrobial peptide, binds and affects pl30(Cas). J Biol Chem 1998, 273:28978-85.

40. Honda H, Nakamoto T, Sakai R, Hirai H: pl30(Cas), an assembling molecule of actin filaments, promotes cell movement, cell migration, and cell spreading in fibroblasts. Biochem Biophys Res Commun 1999, 262:25-30.

4I. Cary LA, Han DC, Polte TR, Hanks SK, Guan JL: Identification of pI30Cas as a mediator of focal adhesion kinase-promoted cell migration. J Cell Biol I998, I40:2II-2I.

42. Wilcox-Adelman SA, Denhez F, Goetinck PF: Syndecan-4 modulates focal adhesion kinase phosphorylation. J Biol Chem 2002, 277:32970-7.

Publish with Biomed Central and every scientist can read your work free of charge

"BioMed Central will be the most significant development for disseminating the results of biomedical research in our lifetime. "

Sir Paul Nurse, Cancer Research UK

Your research papers will be:

- available free of charge to the entire biomedical community

- peer reviewed and published immediately upon acceptance

- cited in PubMed and archived on PubMed Central

- yours - you keep the copyright 